\title{
PENGGUNAAN RENEWABLE ENERGY DIRECTIVE OLEH UNI EROPA UNTUK MENEKANKAN PENOLAKAN IMPOR CRUDE PALM OIL INDONESIA
}

\author{
HERRY WAHYUDI \\ IImu Hubungan Internasional, Universitas Abdurrab, Pekanbaru \\ Herry.wahyudi@univrab.ac.id
}

\begin{abstract}
Abstrak
Uni Eropa (UE) merupakan lembaga yang paling diakui dan dipercaya didunia dalam kaitannya terhadap "Ekolabel" yang dikenal sebagai label yang mengidentifikasi preferensi lingkungan dari keseluruhan produk (barang atau jasa) dalam kategori produk berdasarkan pertimbangan siklus hidup, meskipun UE bersifat sukarela, ratusan perusahaan di seluruh Eropa telah bergabung terkait daya saing dan komitmen UE terhadap lingkungan. Oleh karena itu, Uni Eropa memiliki mekanisme kebijakan yang kompleks dan rumit. Mekanisme kebijakan eco-labelling meliputi serangkaian persyaratan serta alur birokratis yang harus dipenuhi agar suatu produk dapat mendapatkan izin untuk beredar dalam wilayah yurisdiksi Uni Eropa. Renewable Energy Directive (RED) merupakaN salah satu mekanisme yang dikeluarkan oleh Uni Eropa terhadap produk CPO Indonesia yang berdampak terhadap menurunnya ekspor produk CPO Indonesia ke kawasan tersebut. Tulisan ini akan membahas RED sebagai mekanisme yang menekankan CPO Indonesia untuk tidak dapat masuk ke Uni Eropa dalam perspektif Hukum Internasional. Tulisan ini bersifat deskriptif dengan menggunakan metode kualitatif. Hasil dari tulisan ini menunjukkan bahwa penggunaan RED oleh Uni Eropa digunakan sebagai alat penekan untuk produk CPO Indonesia yang akan di ekspor ke kawasan tersebut.

Kata Kunci: Crude palm Oil (CPO), Indonesia, International Law, Renewable Energy Directive (RED), The European Union.
\end{abstract}

\footnotetext{
Abstract

The European Union (EU) is the most recognized and trusted institution in the world in relation to "Ecolabeling" known as a label that identifies the environmental preferences of all products (goods or services) in product categories based on life cycle considerations, although the EU is non-binding framework, hundreds of companies across Europe have joined together regarding EU competitiveness and commitment to the environment. Therefore, the European Union has a complex and complicated policy mechanism. The ecolabeling policy mechanism includes a set of requirements and bureaucratic flow that must be met for a product to obtain permission to circulate within the jurisdiction of the European Union. The Renewable Energy Directive (RED) is one of the mechanisms issued by the European Union for Indonesian CPO products which has an impact on the decline in exports of Indonesian CPO products to the region. This paper will discuss RED as a mechanism that emphasizes Indonesian CPO not being able to enter the European Union in the perspective of International Law. This paper is descriptive using qualitative methods. The results of this paper indicate that the use of RED by the European Union is used as a pressure tool for Indonesian CPO products that will be exported to the region.

Keywords: Crude palm Oil (CPO), Indonesia, International Law, Renewable Energy Directive (RED), The European Union.
} 


\section{PENDAHULUAN}

Perubahan pola tuntutan global hari ini berfokus pada perubahan iklim. Berdasarkan riset IEA tahun 2010, tingkat emisi karbon dioksida dunia terlihat mengalami peningkatan. Produksi energi yang mengandung karbon dapat mempercepat ketidakstabilan perubahan iklim yang akan berdampak pada semua sektor, baik ekonomi, lingkungan, maupun kesehatan manusia. Secara global, ada dorongan yang besar untuk mengembangkan dan menyebarkan teknologi rendah karbon, termasuk energi terbarukan (renewable energy).

Salah satu perhatian utama Uni Eropa terkait isu lingkungan adalah optimalisasi penggunaan energi di negara-negara industri agar tidak terlalu berdampak pada lingkungan. Komitmen dan perhatian Uni Eropa terhadap hal ini mendorong serangkaian kebijakan-kebijakan termasuk ecolabelling, Energy and Climate Change Package, dan Fuel Quality Directive. Renewable Energy Directive (RED) merupakan langkah Uni Eropa untuk memastikan keamanan suplai energi mereka dan mengurangi emisi gas rumah kaca melalui penggunaan bahan bakar terbarukan seperti biofuel sebagai pengganti bahan bakar fosil. RED mendorong negara-negara anggota Uni Eropa untuk menerapkan pemakaian bahan bakar nabati dalam keseharian warganya termasuk transportasi (Schaus and Lendle 2010). Meskipun begitu, produksi minyak dalam Uni Eropa sendiri seperti rapeseed oil tergolong rendah, sehingga Uni Eropa banyak mengekspor bahan bakar nabati dari negara lain, terutama Indonesia. Hubungan perdagangan dalam sektor crude palm oil (CPO) menjadi penting baik bagi Uni Eropa maupun Indonesia. Negaranegara Uni Eropa, dibawah RED, dituntut untuk memenuhi minimal 20\% kebutuhan energi terbarukan hingga tahun 2020 , dengan $10 \%$ dari target sumber daya energi terbarukan tersebut digunakan untuk transportasi. Untuk menempuh $10 \%$ target nasional energi terbarukan, negara-negara Uni Eropa menjadikan energi biofuel dan bioliquid sebagai alternatif (DG-Energy 2015). Energi dari bahan bakar nabati ini selanjutnya banyak diimpor dari negara-negara penghasil CPO seperti Indonesia, Malaysia, ataupun Argentina (Smith et al. 2014).

Sementara itu bagi Indonesia, produk CPO atau minyak sawit mentah merupakan komoditas ekspor potensial yang memberikan kontribusi cukup besar bagi perolehan devisa. Indonesia merupakan produsen CPO terbesar di dunia dengan produksi mencapai volume 20,5 juta ton pada tahun 2009 saja, dan 
memasok 47\% kebutuhan CPO dunia. Pendapatan dari ekspor CPO Indonesia pada tahun 2012 mencapai 21,6 miliar dolar. Dengan kebijakan barunya untuk mengganti penggunaan bahan bakar fosil dengan bahan bakar nabati, Eropa menjadi pasar yang menjanjikan bagi Indonesia. Dari tahun ke tahun, jumlah konsumsi bahan bakar nabati Eropa meningkat. Produk CPO Indonesia dan turunannya yang masuk ke negara-negara Uni Eropa meningkat dari 16,97\% pada tahun 2004 hingga 22,3\% pada tahun 2009 dan membuat Eropa menjadi pasar terbesar bagi produk CPO Indonesia (Smith et al. 2014).

Perdagangan pada sektor bahan bakar nabati tersebut menemui kendala setelah kebijakan RED sustainability standards diimplementasikan. Pada awal tahun 2013, Uni Eropa menghentikan impor dan memberlakukan larangan masuk bagi CPO Indonesia. Hal ini berkaitan dengan green politics yang ditetapkan oleh Uni Eropa, yang membuat akses terhadap pasar dapat dihalangi ketika barang yang diimpor tidak memenuhi standar barang domestiknya. Alasan utama yang diserukan oleh Uni Eropa terkait penolakan terhadap CPO Indonesia adalah masalah lingkungan. Uni Eropa menganggap CPO Indonesia tidak ramah lingkungan. Salah satunya karena penggunaan lahan gambut dan alih fungsi hutan sebagai lahan perkebunan kelapa sawit dianggap menyebabkan deforestasi hutan tropis, hilangnya habitat satwa liar, kebakaran hutan, dan berkontribusi pada penambahan emisi gas rumah kaca. Uni Eropa tidak akan menerima produk CPO Indonesia selama produk tersebut tidak memenuhi standar kriteria energi terbarukan yang digunakan oleh Indonesia.

Sebenarnya, terdapat asumsi bahwa kebijakan green politics yang diterapkan Uni Eropa merupakan strategi untuk menghambat impor barang ke Uni Eropa sekaligus melakukan proteksi dalam negeri terhadap barang substitusi minyak sawit yaitu minyak dari biji bunga matahari yang diproduksi oleh perusahaan domestik Uni Eropa. Minyak dari biji bunga matahari yang diproduksi oleh perusahaan domestik Uni Eropa yang memiliki harga lebih mahal dianggap akan kalah bersaing dengan minyak sawit Indonesia yang memiliki harga lebih murah. Oleh karena itu, standar tinggi yang diterapkan Uni Eropa juga dapat dikatakan hanya memberi keuntungan secara sepihak karena pengekspor minyak nabati berasal dari negara-negara berkembang dan upaya untuk memenuhi standar yang ditetapkan mengeluarkan biaya yang sangat besar. Implikasinya bagi Indonesia apabila tetap berusaha 
memenuhi standar tinggi tersebut, akan berdampak pada meningkatnya biaya produksi minyak sawit itu sendiri. Dengan meningkatkan standar lingkungan tertentu, diperlukan investasi-investasi atau usaha-usaha yang membutuhkan modal yang tidak sedikit sehingga akan mempengaruhi total biaya produksi meningkat sebesar $5 \%-20 \%$ (Schaus and Lendle 2010). Hal ini dapat berdampak pada kehilangan keuntungan komparatif produk minyak sawit Indonesia sehingga menyebabkan produk minyak sawit Indonesia kalah saing karena harganya menjadi jauh lebih mahal. Dapat dikatakan bahwa Uni Eropa menetapkan standar yang tinggi bagi produk impor dalam rangka melakukan proteksionisme terhadap pengembangan produk dalam negeri.

Namun, terlepas dari berbagai alasan politis yang spekulatif, penolakan Uni Eropa dan justifikasi melalui hukum dan kebijakan lingkungan yang dianutnya secara langsung menuntut Indonesia untuk melakukan perubahan dalam cara-cara produksi CPO-nya. Dalam hal ini, perubahan yang dimaksud tentunya membuat produksi CPO dilakukan dengan lebih ramah lingkungan dan memenuhi standar kriteria RED yang ditentukan oleh Uni Eropa. Dapat dikatakan disini bahwa Indonesia kemudian dituntut untuk menerapkan kebijakan lingkungan yang diusung Uni Eropa dalam konsumsi energi dan komoditas lainnya, terutama apabila Indonesia masih melihat Eropa sebagai pasar paling potensial dan menguntungkan pagi produk CPO-nya.

Berdasarkan pemaparan latar belakang diatas, maka pertanyaan penelitian yang diajukan adalah "bagaimana RED sebagai salah satu bentuk Hukum Internasional mampu memaksa Indonesia untuk mengikuti kebijakan lingkungan yang tercantum di dalamnya". Cakupan waktu penelitian adalah ketika Uni Eropa memberikan pernyaaan sikap secara resmi terkait pelaksanaan Directives yang berujung pada penolakan produk CPO ini sekitar tahun 2010 (The Jakarta post 2010).

\section{KERANGKA TEORITIS}

Berdasarkan kasus yang diuraikan diatas, dapat dilihat bahwa justifikasi formal yang diberikan oleh Uni Eropa berkaitan dengan pelestarian lingkungan. Hal ini kemudian dipersempit ke dalam sektor energi terbarukan berdasarkan RED 2009 dan standar kriteria sustainability yang ada didalamnya, yang merujuk kepada penerapan kebijakan ramah lingkungan. 


\section{a. Renewable Energy Directive 2009}

Kebijakan sustainable development muncul dilatarbelakangi atas kondisi ketergantungan atas sumber energi berbahan bakar fosil Uni Eropa. Awalnya Dewan Eropa di Göteborg pada tahun 2001 merumuskan EU Sustainable Development Strategy (SDS) yang pertama, yaitu semaca cetak biru pelaksanaan kebijakan pembangunan Uni Eropa yang lebih bergantung pada sumber energi terbarukan. Karena masih berbentuk stategis, cetak biru ini tidak memiliki kekuatan hukum yang mengikat obyeknya, yakni negara-negara Uni Eropa. Setelah melalui serangkaian amandemen, termasuk dengan adanya perubahan -perubahan pada kurun waktu tahun 2005-2009. pada tahun 2009, Directive 2009/28/EC disahkan oleh the European Parliament and of the Council (European Parliament \& Council of the European Union 2009).

Sesuai dengan ketentuan hukum Uni Eropa, Directives 2009/28/EC penyusunannya berdasarkan Treaty of Lisbon atau yang disebut secara resmi sebagai Treaty of the Establishment of European Community (European Community 1997). Perjanjian yang ditandatangani pada 13 Desember 2007 dan disahkan pada 1 Desember 2009 ini adalah amandemen dari Treaty of Maastricht dan Treaty of Rome yang menjadi dasar konstitusi dan sumber hukum primer Uni Eropa. Karena merujuk langsung pada Treaty of Lisbon, Directive 2009/28/EC adalah produk hukum yang memiliki kekuatan lebih mengikat negara-negara anggota dan memiliki kekuatan hukum tetap dibandingkan SDS (European Community 2015). ${ }^{1}$ Secara umum Directives ini terbagi menjadi dua bagian, yaitu bagian pertama terdiri dari pendahuluan yang berisi penjelasan konseptual yang melatarbelakangi pembentukan Directives, dan yang kedua adalah batang tubuh dari Directives itu sendiri.

Bagian pendahuluan menjelaskan tentang konsep Kebijakan Pembangunan Berkelanjutan yang ditinjau korelasinya dengan kebijakan di sektor lingkungan pada Treaty of Lisbon (European Community 2015). Secara keseluruhan, bagian pendahuluan ini terdiri dari 97 poin berisi penjelasan konsep

\footnotetext{
${ }^{1}$ Menurut hasil putusan the European Court of Justice, 5 Februari 1963 di kasus 26-62 disebutkan mengenai implementasi hukum dari perjanjian pembentukan Uni Eropa dan efeknya bagi negara penandatangan. Sebagai konsekuensi dari penyerahan sebagian kedaulatan negara pada komite Uni Eropa, negara anggota, termasuk warga negaranya harus mematuhi dan menjalankan ketentuan dalam putusan tersebut yang telah disepakati Bersama.
} 
dan korelasinya dengan subyek atau obyek hukum di luar Directives 2009/28/EC. Beberapa poin penting dalam pendahuluan itu adalah sebagai berikut:

a. Pada poin 1-3 dapat ditemukan bahwa desain kebijakan sustainable development Uni Eropa juga mempertimbangkan substansi Protokol Kyoto untuk mengurangi reduksi gas emisi terhitung sejak 2012. Ketentuan di Uni Eropa yang membuat negara tunduk dengan Perjanjian Pendirian Uni Eropa membuat Directives tentang Pembangunan Berkelanjutan ini harus dipatuhi oleh negara-negara anggota. Artinya, negara-negara lain yang aktivitasnya bersinggungan dengan negara anggota Uni Eropa mengenai hal-hal yang diatur dalam Perjanjian Pendirian Uni Eropa juga terdampak dengan hukum ini.

b. Pada poin ke 9, ditemukan adanya keharusan menghasilkan sistem evaluasi yang meliputi keharusan untuk menggunakan biogas secara bertahap untuk pemakaian energi sejak tahun 2010, dan $20 \%$ dari total pemakaian pada 2020, serta amanat untuk menggunakan minimum $10 \%$ dari total konsumsi energi untuk menggunakan biogas yang dibagi bersama penggunaan minyak fosil dan disel pada 2020 (European Community 2015). Program sustainable development Uni Eropa, diharapkan tidak hanya mengatasi krisis energi, namun juga menjamin terciptanya lapangan pekerjaan bagi masyarakat lokal negara-negara anggota Uni Eropa, penciptaan teknologi baru dan penciptaan insentif bagi pihak-pihak yang mampu menemukan teknologi terkait atau menggerakkan proses pembangunan ini. Komite Uni Eropa juga telah membentuk sistem evaluasi kebijakan bagi negara-negara anggota mengenai bagaimana jalannya kebijakan ini di negaranya. Directives 2009/28/EC memberikan keleluasaan bagi negara nggota untuk mendesain jenis pembangunan berkelanjutan seperti apa yang paling cocok namun negara juga harus memastikan bahwa program ini berhasil melewati standar minimum yang diajukan Komite terhitung sejak 2010. Negara memang diperbolehkan mendesain programnya sendiri, namun jika kondisi alam negara anggota tidak memungkinkan untuk mencukupi kebutuhan energi terbarukannya, maka tetap diizinkan melaksanakan transborder energy sharing dan diversifikasi model pembangunan 
berkelanjutan untuk setiap negara anggota. Meskipun hal ini telah diperbolehkan, sesuai pasal 25 negara anggota harus tetap memperhatikan operasionalisasi, dana, penyerapan dan efisiensi dari program energi terbarukan miliknya.

c. Pada bagian pembukaan poin ke 12 juga mengatur tentang jenis-jenis penggunaan produk agrikultur seperti adan residu organik hewan untuk menghasilkan biogas dinilai sebagai salah satu cara untuk mengurasi dampak emisi gas rumah kaca. Instalasi biogas dapat dldesain mengikuti karakteristik daerah negara anggota dan harus mendukung struktur investasi regional, termasuk di daerah pedesaan dan mendorong petani lokal berkesempatan meningkatkan pendapatannya. Selain biogas yang berasal dari residu organik tanaman atau hewan, penggunaan sumbersumber energi terbarukan lain termasuk listrik diperbolehkan asalkan tidak mengganggu kestabilan harga listrik di pasaran (poin 30). Selain listrik beberapa sumber energi seperti daya angin (windpower), penggunaan pompa pemanas (heatpump) dari panas bumi, aerothermal atau sumber panas lainnya juga diperbolehkan.

Pada bagian kedua yaitu batang tubuh, secara umum terdiri dari 29 pasal, yang terkelompokkan dalam beberapa kategori, yang diharapkan dapat menjadi panduan implementasi pelaksanaan program sustainable development. Penjelasannya tidak hanya termasuk pada kriteria bahan mentah yang diperbolehkan digunakan dalam praktik keseharian negara anggota, seperti yang tercantum pada pasal 17 namun juga pada bagaimana pencapaian target nasional, evaluasi, kalkulasi pembagian energi, dan serangkaian sistem lain yamng menjamin bahwa kebijakan ini dapat dijalankan oleh semua negara anggota. Secara keseluruhan, ketentuan mengenai pasal-pasal dan substansi Directives 2009/28/EC dapat dilihat di dalam tabel berikut: 
Tabel 1: Kategori dan Substansi Directive 2009/28/EC

Sumber : Directive 2009/28/EC of the European Parliament and of the Council of 23 April 2009

on the promotion of the use of energy from renewable sources and amending and subsequently repealing Directives 2001/77/EC and 2003/30/EC

\begin{tabular}{|c|c|c|}
\hline KATEGORI & SUBSTANSI & PASAL \\
\hline $\begin{array}{l}\text { Jangkauan subyek } \\
\text { Directives dan definisi }\end{array}$ & $\begin{array}{l}\text { - Penjelasan tentang kerangka pikir dari program sustainable development UE } \\
\text { dan kedudukannya harus diamanatkan pada negara anggota; kaitannya } \\
\text { dengan hukum lain dalam kerangka UE dan penekanan pada target-target } \\
\text { program. } \\
\text { - Penjelasan definitif seputar kebijakan lingkungan seperti: energi, energi } \\
\text { aerothermal, biothermal, biomass, konsumsi total energi, 'renewable energy } \\
\text { obligation. }\end{array}$ & $1-2$ \\
\hline Kriteria Target Nasional & $\begin{array}{l}\text { Penjabaran mengenai bagaimana target kebijakan ini diamananatkan pada } \\
\text { negara } \\
\text { - visi tahun } 2020 \text { yang mewajibkan total penggunaan sumber bahan bakar } \\
\text { terbarukan minimal } 20 \% \text { dari total konsumsi bahan Uni Eropa (ayat } 1 \text { ). } \\
\text { - kewajiban negara agar program ini terlaksana dengan baik dan } \\
\text { pembentukan skema pendukung (ayat } 2-3 \text { ). } \\
\text { - kewajiban negara untuk memastikan bahwa target pemakaian energi } \\
\text { terbarukan untuk segala jenis moda transportasi minimal mencapai } 10 \% \\
\text { pada tahun } 2010 \text { untuk tiap negara (ayat4). }\end{array}$ & 3 \\
\hline $\begin{array}{l}\text { Action plan Kebijakan } \\
\text { Energi Terbarukan } \\
\text { Nasional }\end{array}$ & $\begin{array}{l}\text { Berisi tentang detail ketentuan pelaksanaan action plan oleh masing-masing } \\
\text { negara anggota untuk: } \\
\text { - } \quad \text { mulai beralih pada suber energi perbarukan terhitung sejak tahun } 2010 \text {, } \\
\text { terutama di sektor transportasi, pemanas, pendingin dan kelistrikan (1). } \\
\text { - keharusan negara melakukan pelaporan rutin tiap tahun dan publikasi tiap } 6 \\
\text { bulan pada Komisi Uni Eropa tentang pelaksanaan action plan (2-3). }\end{array}$ & 4 \\
\hline
\end{tabular}




\begin{tabular}{|c|c|c|}
\hline $\begin{array}{l}\text { Perhitungan pembagian } \\
\text { energi dan statistika } \\
\text { transfer sumber daya } \\
\text { terbarukan }\end{array}$ & $\begin{array}{l}\text { Penjelasan tentang ketentuan perhitungan pembagian energi negara anggota } \\
\text { Uni Eropa, terutama penggunaan sumber-sumber energi terbarukan yang } \\
\text { digunakan lebih dari } 1 \text { negara anggota. }\end{array}$ & $5-6$ \\
\hline Ketentuan Joint Projects & $\begin{array}{l}\text { Mengatur ketentuan tentang joint project untuk mempeoleh sumber daya } \\
\text { terbarukan, baik dengan sesama negara anggota UE, negara lain (pihak } \\
\text { ketiga) serta efek yang diperoleh. }\end{array}$ & $7-10$ \\
\hline $\begin{array}{l}\text { Skema joint support dan } \\
\text { peningkatan kapasitas }\end{array}$ & $\begin{array}{l}\text { - Ketentuan yang harus dipenuhi, bilamana negara anggota berkehendak } \\
\text { membuat join support, kententuan pelaksanaan dan pelaporan kegiatan. } \\
\text { - Aturan yang mengharuskan negara meningkatkan kapasitas instalasi } \\
\text { penghasil sumber energi terbarukan sekaligus perawatannya. }\end{array}$ & $11-12$ \\
\hline $\begin{array}{l}\text { Prosedur Administratif, } \\
\text { Aturan dan Kode Etik }\end{array}$ & $\begin{array}{l}\text { Kewajiban negara unutk meastikan bahwa kebijakan ini telah terdifusi dalam } \\
\text { peraturan domestik negara, termasuk dalam otorisasi, sertifikasi dan penerbitan } \\
\text { lisensi untuk menjamin transmisi dan distribusi energi terbarukan yang telah } \\
\text { dipilih untuk dijalankan di negaranya. }\end{array}$ & 13 \\
\hline Informasi dan Pelatihan & $\begin{array}{l}\text { Kewajiban negara unutk memberikan pelatihan dan akses informasi yang } \\
\text { memadai bagi pihak-pihak yang ingin berpartisipasi menjalankan/melakukan } \\
\text { riset tentang sumber energi terbarukan, terhitung sejak } 31 \text { Desember } 2012 \text {. }\end{array}$ & 14 \\
\hline $\begin{array}{l}\text { Jaminan asal sumber } \\
\text { listrik, pendingin dan } \\
\text { pemanas yang berasal } \\
\text { dari sumber energi } \\
\text { terbarukan }\end{array}$ & $\begin{array}{l}\text { Setiap sumber energi yang diproduksi untuk pendingin, penghangat ataupun } \\
\text { sumber listrik, negara harus menjamin asal sumber energi tersebut adalah } \\
\text { sumber energi terbarukan. Selain itu harus diapstikan pula dalam proses } \\
\text { pendaftarannya, setiap negara hanya mendaftarkan satu jenis instalasi sumber } \\
\text { energi pada satu kategori saja. }\end{array}$ & 15 \\
\hline $\begin{array}{l}\text { Akses pada poerasional } \\
\text { instalasi sumber energy }\end{array}$ & $\begin{array}{l}\text { Negara menjamin ketersediaan infratruktur untuk transimsi energi dari sumber } \\
\text { terbarukan ini, bertanggungjawab pada proses perawatan dan mudah diakses } \\
\text { publik sebagai fungsi kontrol, namun memperhatikan kapasitas dan resiko } \\
\text { pembangunan instalasi tersebut. }\end{array}$ & 16 \\
\hline
\end{tabular}




\begin{tabular}{|c|c|c|}
\hline $\begin{array}{l}\text { Kriteria "sustainability" } \\
\text { dalam bioliquid dan } \\
\text { biofuel dan mekanisme } \\
\text { proses verifikasi } \\
\text { kepatuhan atas aturan } \\
\text { tersebut }\end{array}$ & $\begin{array}{l}\text { Mengatur tentang bagaimana bahan mentah yang digunakan sebagai bahan } \\
\text { bakar energi terbarukan yang didatangkan dari wilayah lain. } \\
\text { - } \text { harus memenuhi target nasional dan kriteria-kriteria yang diterapkan } \\
\text { (minimal mampu mengurangi emisi gas rumah kaca sebesar } 35 \% \text { yang } \\
\text { terus meningkat hingga } 50 \% \text { pada } 2017 \text { ). } \\
\text { - Pelarangan penggunaan produk kehutanan yang jelas digunakan untuk } \\
\text { tujuan konservasi atau perlindungan lain seperti tempat tinggal } \\
\text { komunitas/suku asli suatu daerah atau habitat satwa langka dan taman } \\
\text { konservasi. } \\
\text { - Kewajiban Komisi UE untuk memantau dan melaporkan pada Parlemen dan } \\
\text { Dewan UE atas kondisi lahan dimana bahan mentah untuk sember energi } \\
\text { terbarukan ini diambil, apakah benar-benar sesuai dengan kondisi yang } \\
\text { ditetapkan UE atau tidak. } \\
\text { - Kepastian bahwa bahan mentah yang digunakan sebagai sumber energi } \\
\text { terbarukan tidak melanggar konvensi terkait perlindungan lingkungan dan } \\
\text { satwa/tanaman yang terancam punah. }\end{array}$ & $17-18$ \\
\hline $\begin{array}{l}\text { Kalkulasi dampak emisi } \\
\text { gas biofuel dan bioliquids }\end{array}$ & $\begin{array}{l}\text { Perhitungan emisi gas buang dari biofuel maupun bioliquid menggunakan } \\
\text { formula yang tercantum dalam lampiran sebagai udaha untuk memastikan } \\
\text { nahwa total residunya tidak lebih besar dari bahan bakar fosil. }\end{array}$ & 19 \\
\hline $\begin{array}{l}\text { Implementasi Aturan dan } \\
\text { Korelasi dengan } \\
\text { Kebijakan Energi } \\
\text { Terbarukan Sebelumnya }\end{array}$ & $\begin{array}{l}\text { Detail pelaksanaan kebijakan yang dirujuk pada pasal sebelumnya dalam } \\
\text { Directives ini dan kaitannya dengan Directive lain yang diterbitkan sebelumnya } \\
\text { yang sama-sama mengatur tentang kebijakan sustainable development } \\
\text { dibidang transportasi publik (Directive 2003/54/EC; pasal } 7 a \text { of Directive } \\
\text { 98/70/EC). }\end{array}$ & $20-21$ \\
\hline
\end{tabular}




\begin{tabular}{|c|c|c|}
\hline $\begin{array}{l}\text { Mekanisme Pelaporan } \\
\text { Tahunan, Monitoring oleh } \\
\text { Komite dan Prinsip } \\
\text { Transparansi }\end{array}$ & $\begin{array}{l}\text { Penjelasan mengenai: } \\
\text { - tata cara pelaporan rutin tiap tahun oleh negara anggota pada Komite tentang } \\
\text { penggunaan bahan baku sumber energi terbarukan yang digunakan. } \\
\text { - penjelasan Mekanisme monitoring yang diterapkan Komite untuk menastikan } \\
\text { sistem tetap berjalan di negara anggota. } \\
\text { - intrepretasi prinsip transparansi baik untuk negara anggota sebagai pelapor } \\
\text { kondisi pelaksanaan program maupun Komite. } \\
\text { - Penjelasan tentang kedudukan, tugas dan fungsi Komite (dengan nama resmi } \\
\text { Committee on Renewable Energy Sources). }\end{array}$ & $22-25$ \\
\hline $\begin{array}{l}\text { Amandemen, Transposisi, } \\
\text { Kesepakatan Penerapkan, } \\
\text { dan Penjelasan Obyek } \\
\text { Hukum Directives }\end{array}$ & $\begin{array}{l}\text { Penyesuaian terbaru mengenai beberapa amandemen hingga tahun } 2012 \text {, } \\
\text { penjelasan batas waktu minimal Directives ini efektif diterapkan di negara } \\
\text { anggota dan penjelasan tentang obyek hukum Directive ini, yaitu semua negara } \\
\text { Uni Eropa. }\end{array}$ & $26-29$ \\
\hline
\end{tabular}


Aturan yang terdapat dalam Directives tersebut mengarahkan negara-negara Uni Eropa terhadap penggunaan bahan bakar nabati sebagai energi terbarukan menggantikan bahan bakar fosil. Tentu saja, karena salah satu tujuan pemakaian bahan bakar nabati tersebut berkaitan dengan pelestarian lingkungan, bahan bakar yang digunakan oleh negara-negara anggota Uni Eropa juga harus memenuhi standar keamanan lingkungan yang diterapkan oleh Uni Eropa. Untuk itu, terdapat beberapa standar kriteria yang harus dipenuhi oleh produk impor - dalam kasus ini produk CPO Indonesia - agar dapat diterima sesuai hukum dan aturan yang berlaku di Eropa.

\section{b. European Union Sustainability Standard}

Dalam pasal 17 Directives 2009/28/EC bahan bakar nabati yang disebut berkelanjutan atau sustainable memiliki dua kriteria mendasar yang harus dipenuhi. Salah satu standar utama yang ditekankan oleh Uni Eropa adalah produksi gas rumah kaca atau greenhouse gas (GHG). Salah satu tujuan pemakaian bahan bakar nabati adalah karena bahan bakar tersebut mampu menurunkan emisi GHG. Namun permasalahannya, proses produksi bahan bakar nabati itu sendiri tidak bebas dari emisi. Uni Eropa kemudian membuat standar ambang pengurangan emisi sebanyak 35\% hingga tahun 2016, 50\% pada 2017, hingga 60\% pada tahun 2018 (European Community 2015). Uni Eropa juga menyertakan detail metode penghitungan nilai emisi karbon pada suatu produk dalam lampirannya yang dinilai dari penanaman dan pemanenan bahan mentah, penggunaan lahan, proses pembuatan, dan transport serta distribusi.

Yang menjadi masalah adalah pada dasarnya emisi karbon yang dihasilkan dari proses pertanian CPO di Indonesia. Untuk pembersihan lahan saja, tanah yang digunakan di Indonesia menghasilkan 500 hingga 900 ton karbondioksida setiap hektarnya (Block 2014). Ini belum termasuk karbon yang dihasilkan dari pembakaran lahan yang digunakan untuk pertanian. Emisi yang dihasilkan dari pembakaran, oksidasi lahan, dan hilangnya biomasa mencapai 903 metrik ton per tahun pada jenjang tahun 2000-2006 saja (Bappenas 2009). Berdasarkan penghitungan, minyak kelapa sawit terutama yang diproduksi tanpa penangkapan methane hanya mampu memenuhi standar pengurangan emisi hingga 19\% saja (European Parliament \& Council of the European Union 2009). 
Selanjutnya, dalam pasal 17 ayat 3-5 terdapat standar mengenai jenis tanah yang digunakan untuk penanaman kelapa sawit. Pertama, tanah yang digunakan tidak boleh berasal dari hutan lindung maupun area yang apabila digunakan dapat membahayakan biodiversitas lingkungan. Kedua, tidak boleh menggunakan tanah yang mengandung banyak karbon, terutama karena aturan ambang batas emisi karbon terhitung mulai dari penanaman kelapa sawit itu sendiri. Ketiga, penanaman juga tidak boleh dilakukan di lahan gambut (European Parliament \& Council of the European Union 2009).

Berdasarkan laporan yang dilakukan oleh komunitas-komunitas pelestarian hutan seperti Forest Heroes, perusahaan-perusahaan penghasil minyak kelapa sawit di Indonesia banyak diletakkan dalam daftar kuning dan merah-perusahaan yang dinilai sebagai suplier yang tidak bertanggungjawab terhadap kelestarian lingkungan dalam produksinya. Dalam daftar laporan Green Tiders, yang disusun berdasarkan produksi perusahaan-perusahaan ini dikaitkan dengan perlindungan terhadap hutan, kandungan karbon, lahan gambut, dan hak asasi manusia, kebanyakan perusahaan Indonesia dinilai buruk. Diantaranya adalah Asian Agri, Bumitama Agri Ltd (daftar kuning-serious issues in suply chain), Astra Agro Lestari, Indofood, dan KLK (daftar merah-irresponsible suppliers) (G. Hurowitz 2015). Asian Agri telah dinilai selama bertahun-tahun berkontribusi terhadap deforestation, terutama karena perusahaan ini melakukan pertanian dalam area Taman Nasional Tesso Nilo, satu dari sedikit tempat yang masih memiliki harimau, kuda nil, orangutan, dan gajah dalam satu habitat yang sama. Bumitama disinyalir telah melakukan penggundulan hutan seluas 20.000 hektar. KLK dicurigai sebagai pelaku pembakaran hutan secara sengaja, dan Indofood dinilai hanya memiliki sedikit kebijakan sustainability dan hanya memiliki sertifikat RSPO untuk kurang dari sepertiga produknya saja ditahun 2012. Astra Agro Lestari, sementara itu, dinilai melakukan penggundulan hutan dan perusakan lahan gambut di hutan rawa Tripa di Sumatera dan merusak ekosistem orangutan disana (G. Hurowitz 2015).

\section{c. Hukum Uni Eropa sebagai Hukum Supranasional}

Hukum dalam Uni Eropa diterbitkan dalam dua jenis, yaitu Regulation dan Directive. Hukum ini merupakan bagian dari hukum supranasional yang dipakai di Uni Eropa. Hukum supranasional sendiri dapat diartikan sebagai suatu bagian hukum yang 
diproduksi oleh sistem yang terogranisir yang didasarkan pada perjanjian internasional (Council of Europe 1993). Berdasarkan hasil putusan the European Court of Justice, 5 Februari 1963 di kasus 26-62 disebutkan mengenai implementasi hukum dari perjanjian pembentukan Uni Eropa dan efeknya bagi negara penandatangan, pada dokumen itu sebagai konsekuensi dari penyerahan sebagian kedaulatan negara pada komite Uni Eropa, negara anggota, termasuk warga negaranya harus mematuhi dan menjalankan hak dan kewajiban dalam putusan tersebut yang telah disepakati bersama. Ini artinya negara-negara anggota Uni Eropa menerima hukum dan aturan yang diterapkan secara otomatis (Council of Europe 1993).

Dengan demikian Renewable Energy Directive atau Directive/2009/28/EC harus diterima dan diikuti oleh semua negara anggota Uni Eropa tanpa terkecuali. Berdasarkan substansi yang telah dipaparkan diatas, negara-negara Uni Eropa diharuskan menggunakan bahan bakar terbarukan minimal 20\% dari keseluruhan penggunaan bahan bakar mereka pada tahun 2020. Bahan bakar nabati sebagai bahan bakar terbarukan juga harus memenuhi standar kriteria berkelanjutan yang diatur dalam pasal 17. Dengan kata lain, produk yang tidak memenuhi kriteria tersebut tidak dapat masuk ke dalam pasar Eropa untuk dikonsumsi. Meskipun, misalnya, importir bahan bakar nabati di Eropa tidak berkeberatan dengan produk tanpa label sustainable, berdasarkan hukum Uni Eropa produk tersebut tidak diperbolehkan untuk digunakan.

\section{METODE PENELITIAN}

Metode yang digunakan dalam penulisan karya ilmiah ini ialah metode kualitatif dengan teknik pengumpulan data sekunder yang diperoleh melalui metode kepustakaan (library research). Data diperoleh dan dikumpulkan melalui beberapa studi kajian terdahulu dan analisis dokumen seperti: buku, artikel, jurnal, dan laporan yang terkait dengan penulisan karya ilmiah ini. 


\section{PEMBAHASAN}

\section{A. Respon Indonesia terhadap Penolakan Produk CPO oleh Uni Eropa}

Indonesia memiliki dua pilihan dalam menghadapi penolakan produk CPO oleh Uni Eropa. Pilihan pertama adalah beralih pada pangsa pasar lain yang tidak memiliki standar dan aturan seketat Uni Eropa, Pilihan kedua adalah tetap bertumpu pada Uni Eropa sebagai pasar utama CPO dengan mau tidak mau memenuhi standar kriteria sustainability yang ditetapkan oleh Eropa. Perlu diingat disini, bahwa CPO merupakan salah satu komoditi yang sangat berperan penting bagi perekonomian Indonesia. Peranan penting ini dapat dilihat dari perkembangan produksi CPO yang meningkat dari tahun ke tahun dibandingkan dengan komoditi lain. Uni Eropa merupakan pasar nomor satu Indonesia untuk produk CPO, Konsekuensi dari meninggalkan Uni Eropa sebagai pasar utama CPO Indonesia akan mengurangi pemasukan negara, terutama dari sektor pertanian.

Di sisi lain, penolakan Uni Eropa yang didasarkan pada aturan dan kriteria valid, secara langsung turut memperburuk citra Indonesia di kalangan pemerhati lingkungan. Langkah penolakan Uni Eropa kemungkinan besar diikuti negara-negara pengimpor CPO lain seperti Amerika Serikat. Berdasarkan kalkulasi cost and benefit yang ada, akan lebih rasional bagi Indonesia untuk mengikuti ketentuan yang ditetapkan oleh Uni Eropa terkait produk CPO nya, yaitu memenuhi kriteria penanaman yang ramah lingkungan dan sesuai dengan standar kebijakan lingkungan yang ditetapkan dalam RED.

\section{B. Peraturan Menteri Pertanian}

Langkah Indonesia dalam menanggapi dan menghadapi kebijakan green policy yang diterapkan oleh Uni Eropa terhadap impor CPO Indonesia ke Uni Eropa ialah dengan mensinergikan kebijakan produksi dalam negeri dan kebijakan perdagangan di luar negeri oleh kedua belah pihak. Setelah Uni Eropa menolak masuknya produk CPO dari Indonesia pada tahun 2013, Indonesia mulai memperketat pengawasan peraturan produksi minyak kelapa sawit nya yang sebelumnya telah diatur dalam Peraturan Menteri Pertanian No. 19/Permentan/OT/140/3/2011 tentang Pedoman Perkebunan Kelapa Sawit Berkelanjutan Indonesia (Indonesian Sustainable Palm Oil - ISPO) dengan menerapkan prinsip-prinsip pembangunan perkebunan 
berkelanjutan (sustainable) yang disesuaikan dengan berbagai peraturan perundang-undangan yang berlaku (ISPO 2015).

Sebelum Pemerintah Indonesia mengeluarkan ketentuan mengenai ISPO, pasar Internasional telah lebih dahulu menilik mengenai ketentuan memproduksi kelapa sawit berkelanjutan yang diramu dalam bentuk RSPO (Lembaga Riset Perkebunan Indonesia 2009). Perbedaan antara RSPO dan ISPO terletak pada sifat pengaturannya. Apabila ISPO bersifat mandatory (kewajiban) maka RSPO bersifat voluntary (sukarela). Perusahaan perkebunan sawit yang dapat mengajukan permohonan sertifikasi ISPO harus memenuhi beberapa persyaratan. Misalnya, sudah mendapat penilaian sebagai kebun kelas 1, kelas 2, dan kelas 3 . Penilaian ini sesuai dengan Permentan No. 7 Tahun 2009 tentang Pedoman Penilaian Usaha Perkebunan. Berbeda dengan RSPO, ISPO disusun berdasarkan peraturan perundangan yang berlaku di Indonesia dan berbagai institusi terkait. Misalnya Kementerian Pertanian, Kementerian Kehutanan, Kementerian Lingkungan Hidup, Kementerian Tenaga Kerja dan Transmigrasi dan Badan Pertanahan Nasional.

ISPO bersifat mandatory atau kewajiban karena didasarkan pada peraturan yang dibuat oleh pemerintah Indonesia. Dimulai sejak Maret 2011, perusahaan perkebunan kelapa sawit dalam waktu paling lambat sampai dengan tanggal 31 Desember 2014 harus sudah melaksanakan usahanya sesuai dengan ketentuan dalam peraturan ini yang nantinya dibuktikan dengan pemberian sertifikat ISPO. Sistem ini adalah suatu kebijakan yang diambil oleh pemerintah dalam memberikan perhatian lebih terhadap citra kelapa sawit Indonesia di pasar dunia, menjaga komitmen terhadap lingkungan, sesuai dengan tuntutan pasar dan mengurangi emisi gas rumah kaca. Sejauh ini, Kementerian Pertanian telah memberikan sertifikat ISPO kepada 10 perusahaan perkebunan yang dianggap telah memenuhi persyaratan ISPO sesuai dengan peraturan Menteri Pertanian no. 9/Permentan/OT.140/3/2011 (Biro Umum Humas 2015).

\section{RSPO-RED}

Lebih spesifik menyangkut persayaratan dan kriteria yang terdapat dalam RED 2009, terdapat skema RSOP-RED yang memungkinkan produsen CPO untuk dapat memenuhi kriteria yang diterapkan Uni Eropa dalam Directive/2009/28/EC. 
Persyaratan RSPO-RED yang disesuaikan dengan persyaratan Undang-Undang tentang Energi Terbarukan Uni Eropa - Versi 4, dirancang sebagai tambahan yang bersifat sukarela di dalam Principles \& Criteria RSPO dan akan memungkinkan produsen dan prosesor minyak sawit dalam keadaan tertentu dapat memenuhi persyaratan Directives/2009/28/EC tentang promosi penggunaan energi dari sumber terbarukan. Directives ini menentukan persyaratan berkelanjutan biofuel dan bioliquid di Uni Eropa.

Persyaratan RSPO-RED secara khusus memungkinkan produsen yang lahannya sedang digunakan untuk kultivasi minyak sawit pada bulan Januari 2008 untuk memenuhi persyaratan EU-RED jika sejumlah persyaratan tambahan lainnya telah dipenuhi. Persyaratan ini juga memungkinkan operator dari rantai pasokan yang mendapatkan minyak sawit dari produsen untuk memenuhi persyaratan RED tertentu. Perkebunan yang didirikan setelah Januari 2008 tidak dapat disertifikasi melalui skema RSPO-RED.

Antisipasi yang dapat dilakukan adalah RSPO akan mengembangkan alat perhitungan gas rumah kaca atau RSPO akan menilai dan menyetujui alat perhitungan gas rumah kaca yang disetujui EU-RED saat ini untuk digunakan dengan persyaratan RSPO-RED. Alat mana pun yang dikembangkan oleh RSPO akan dikirimkan ke EC untuk "divalid-REDasi" dan disetujui sebelum dapat digunakan untuk persyaratan RSPO-RED.

Persyaratan RSPO-RED dirancang untuk digunakan bersamaan dengan Principles \& Criteria RSPO, persyaratan Sistem Sertifikasi RSPO, persyaratan Sistem Sertifikasi Rantai Pasokan RSPO, dan Standar Sertifikasi Rantai Pasokan RSPO. Persyaratan RSPO-RED berlaku di semua negara tanpa memandang perbedaan Interpretasi Nasional RSPO saat ini maupun di masa yang akan datang. Semua Persyaratan RSPO-RED bersifat wajib untuk operator rantai pasokan yang ingin mematuhi persyaratan EU-RED. Klaim hanya dapat dilakukan terkait pemenuhan persyaratan RSPO-RED jika operator telah berhasil menilai sesuai persyaratan RSPO-RED. 


\section{Analisis: Penolakan CPO sebagai Instrumen Penekan Implementasi}

\section{Kebijakan Lingkungan Uni Eropa}

\section{a. Kebijakan Lingkungan Uni Eropa}

Uni Eropa merupakan salah satu pihak yang paling mengedepankan kebijakan lingkungan dalam agenda-agendanya. Sejak munculnya isu lingkungan pada forum debat garda depan sekitar akhir tahun 1960-an dan awal tahun 1970-an, Uni Eropa yang saat itu masih berupa Komunitas Ekonomi Eropa segera menyadari signifikansi isu tersebut untuk dihadapi secara bersama. Environment Action Program yang ditisukan pada tahun 1973 menandai kepedulian Uni Eropa terhadap isu lingkungan (Jordan 2005). Semenjak itu, lebih dari empat puluh tahun kemudian, Uni Eropa terus menjadi garda depan institusi pemerintahan yang meletakkan isu lingkungan sebagai isu penting dalam agenda-agendanya, juga mempelopori berbagai perjanjian dan pembentukan hukum lingkungan internasional termasuk mendorong negara-negara untuk meratifikasi Protokol Kyoto.

Bagaimana energi terbarukan berhubungan dengan lingkungan terdapat pada maksud dan tujuan penggunaanya. Pada dasarnya kebijakan pemakaian energi terbarukan adalah adanya ketergantungan kepada bahan bakar fosil yang selain semakin mendekati kelangkaan, juga berpotensi besar pada kerusakan lingkungan terkait dengan masalah polusi dan emisi karbon. RED 2009 pada dasarnya dibuat dengan acuan kepada Protokol Kyoto dan UNFCC yang merupakan international environmental law. Secara prinsip, kebijakan energi terbarukan merupakan salah satu rangkaian kebijakan lingkungan yang dimiliki oleh Uni Eropa. Terlebih lagi, dalam RED tersebut tercantum standar kriteria bahan bakar yang boleh digunakan oleh Uni Eropa, yaitu bahan bakar berkelanjutan yang dalam pembuatan dan pemakaiannya tidak mengakibatkan kerusakan lingkungan ataupun menambah emisi karbon gas rumah kaca.

Dapat dipahami kemudian apabila penolakan produk CPO Indonesia oleh Uni Eropa disertai dengan alasan menyangkut pelestarian lingkungan. Dapat dilihat dalam uraian sebelumnya bahwa Indonesia dinilai melakukan banyak kerusakan lingkungan dari produksi minyak kelapa sawitnya, termasuk pengeringan lahan gambut, penggunaan lahan yang mengandung emisi karbon dalam jumlah tinggi, hingga penggundulan dan pembakaran hutan yang bukan hanya mengakibatkan 
meningkatnya emisi karbon, polusi asap, dan hujan asam namun juga rusaknya habitat satwa dan biodiversitas yang ada.

Penolakan Uni Eropa ini memang mengundang asumsi adanya tindakan proteksionisme terhadap produksi bahan bakar nabati dalam Uni Eropa sendiri. Bahan bakar nabati produksi Uni Eropa seperti minyak rapeseed memang jauh kalah populer dibandingkan minyak kelapa sawit yang lebih murah dari sisi harga dan lebih efisien dari sisi produksi. Uni Eropa kemudian dianggap melakukan proteksionisme terhadap produksi domestik bahan bakar nabati melalui klaim lingkungan dan dumping.

Penolakan Uni Eropa terhadap produk bahan bakar nabati bukan hanya dari Indonesia, tapi juga dari negara-negara lain dapat digolongkan sebagai pelanggaran terhadap aturan WTO. Misalnya, dalam pasal III GATT yang menyebutkan mengenai larangan perlakukan berbeda terhadap produk impor dan produk lokal (GATT 1986). Larangan pembatasan terhadap impor juga dimuat dalam pasal XI GATT, sementara sustainability criteria dapat dihubungkan dengan pasal I GATT tentang Most Favoured Nations, dimana kriteria yang ada dapat dianggap hanya menguntungkan bagi negara tertntu saja yang memiliki teknologi lebih maju.

Namun, untuk alasan yang sama Uni Eropa juga dapat melakukan tuduhan bahwa negara-negara produsen CPO melakukan pelanggaran terhadap pasal II ayat 2 poin (b) GATT dan pasal VI GATT mengenai anti-dumping, seperti halnya yang selama ini menjadi salah satu alasan penolakan Uni Eropa. Hanya saja terkait masalah lingkungan, Uni Eropa memiliki klaim yang lebih jelas tanpa melalui forum WTO. RED 2009 memberikan Uni Eropa hak untuk menolak produk-produk yang tidak sesuai dengan kriteria yang ditetapkan. Dalam hal ini, klaim Uni Eropa berupa perusakan lingkungan dan ketidaksesuaian produk CPO Indonesia dengan kriteria yang telah ditetapkan dalam Undang-Undang Uni Eropa adalah sah secara hukum dan bukan merupakan tindakan proteksiosme, selama Uni Eropa bersedia menerima kembali produk CPO yang telah mendapatkan label sustainable dan memenuhi kriteria yang telah disebutkan diatas. 


\section{b. Compliance Indonesia terhadap kebijakan lingkungan Uni Eropa dalam}

\section{produksi CPO sebagai dampak dari penolakan Uni Eropa}

Dalam sub-bab sebelumnya telah dibahas bagaimana Indonesia kemudian memilih untuk menerima klaim Uni Eropa yang ditunjukkan dengan perbaikan-perbaikan pada sistem pertanian dan produksi CPO melalui pemenuhan kriteria sustainable yang disyaratkan dalam RED 2009. Hal ini menunjukkan bahwa alih-alih mengajukan tuntutan pada Uni Eropa melalui WTO seperti yang dilakukan oleh Argentina (Reuters 2013), Indonesia memilih untuk patuh pada tuntutan Uni Eropa dan mengadopsi kebijakan lingkungan dalam sektor produksi CPO yang ada di Indonesia.

Dasar hukum yang digunakan oleh Uni Eropa tidaklah secara langsung digunakan untuk menekankan bahwa Indonesia harus menggunakan kebijakan lingkungan secara keseluruhan. Faktor lingkungan dan RED digunakan oleh Uni Eropa untuk menolak masuknya produk CPO Indonesia yang tidak sesuai dengan kriteria sustainability yang ditetapkan dalam RED—artinya, CPO yang dianggap merusak lingkungan. Indonesia tidak kemudian secara langsung melanggar hukum internasional mengenai lingkungan, kecuali prinsip-prinsip yang terkandung dalam REDD+ dan Protokol Kyoto, dimana Indonesia telah menegaskan komitmen untuk bergabung dengan gerakan global mengatasi perubahan iklim (M.A. Suleiman 2014), termasuk pengurangan emisi gas rumah kaca dan pelestarian hutan.

Apa yang dilakukan Uni Eropa dengan menolak produk CPO Indonesia sesuai dengan RED 2009, adalah meletakkan Indonesia pada dua pilihan. Pertama yaitu mengubah pasar CPO Indonesia, atau kedua yaitu tetap menjadikan Eropa pasar CPO Indonesia dengan memenuhi kriteria-kriteria yang telah ditentukan oleh Uni Eropa berdasarkan RED 2009. Melihat bahwa Uni Eropa merupakan pasar terbesar bagi produk CPO Indonesia, pilihan kemudian jatuh pada poin kedua, yaitu berupaya untuk menjadikan CPO Indonesia memenuhi standar kriteria sustainability yang ditetapkan oleh Uni Eropa.

Dengan demikian, secara tidak langsung, Uni Eropa membuat Indonesia harus patuh pada tuntutan kriteria produk yang distandarkan Uni Eropa, yang hanya dapat diraih melalui implementasi kebijakan lingkungan yang signifikan dan berkelanjutan dalam produksi CPO Indonesia. 


\section{KESIMPULAN}

Berdasarkan uraian yang telah disampaian diatas, ada tiga hal utama yang dapat diidentifikasi dari kasus penolakan Uni Eropa terhadap produk CPO Indonesia, yaitu: pertama, penolakan tersebut diletakkan atas dasar hukum yang valid, yaitu UndangUndang dalam Uni Eropa yang berbentuk Directives-memiliki set tujuan yang jelas namun tidak disertai tuntutan spesifik pada metode yang digunakan (European Union 2016) dan merupakan bagian dari hukum yang bersifat supranasional, dan karenanya harus diikuti dan dipatuhi oleh semua anggota Uni Eropa berdasarkan ketentuan dalam perjanjian pembentukan Uni Eropa. Dalam kasus ini, Directives yang digunakan adalah Renewable Energy Directive yang dibentuk pada 23 April 2009 (Directives/2009/28/EC) mengenai penggunaan energi terbarukan dan terutama sustainability criteria yang terkandung dalam pasal 17. Kedua, Uni Eropa dalam kasus ini bertindak sebagai aktor penekan karena yang merumuskan RED itu sendiri adalah Komisi Eropa serta epistemic community yang memiliki otoritas atau kemampuan dalam bidang ini dan telah disetujui oleh Dewan Uni Eropa. Berdasarkan sifatnya yang supranasional, RED harus diikuti oleh semua negara, dimana hal ini memiliki arti bahwa bahan bakar nabati yang digunakan oleh negara anggota Uni Eropa mau tidak mau harus sesuai dengan ketentuan dalam RED.

Ketiga, Indonesia bertindak sebagai pihak yang ditekan_karena secara tidak langsung Indonesia dihadapkan pada kebijakan satu arah yang sumbernya berasal dari Uni Eropa itu sendiri. Meskipun secara tidak langsung, namun penolakan Uni Eropa mampu membuat Indonesia kemudian menerapkan kebijakan pertanian yang lebih ramah lingkungan sesuai dengan RED 2009. Dalam kasus ini, kita dapat melihat bagaimana suatu hukum dapat digunakan oleh suatu pihak atau negara untuk membuat negara lain mengambil kebijakan yang tidak diambil sebelumnya, dan berada dalam lingkup kepentingan pihak pertama. Uni Eropa secara tidak langsung membuat Indonesia mengaplikasikan kebijakan lingkungan seperti yang selama ini digunakan oleh Uni Eropa melalui penolakan mereka terhadap produk CPO Indonesia yang didasarkan pada ketentuan yang ada dalam Renewable Energy Directive 2009. 


\section{REFERENSI}

Bappenas. 2009. Reducing Carbon Emissions from Indonesia's Peat Lands. Interim Report of a Multidisciplinary Study.

Biro Umum Humas. 2015. "Pemerintah Berikan Sertifikasi Kepada 10 Perusahaan Perkebunan."

Block, Ben. 2014. "Global Palm Oil Demand Fueling Deforestation." Worldwatch Insitute (0). http://www.worldwatch.org/node/6059 (March 20, 2015).

Council of Europe. 1993. "Human Rights Centre and Supported by the Phare Programme of the European Communities." In The Relationship Between International and Domestic Law: Proceedings of the UniDem Seminar Organised in Warsaw on 19 to 21 May 1993, in Co-Operation with the University of Wroclaw and the Poznań, Warsawa, 79.

DG-Energy. 2015. "Renewable Energy Directive." European Comission (April 2009): 2011. https://ec.europa.eu/energy/en/topics/renewable-energy/renewableenergy-directive (March 20, 2015).

European Community. 1997. "Consolidated Version of the Treaty Establishing the European Community." Official Journal of the European Communities 325: 173306. http://eur-lex.europa.eu/legalcontent/EN/TXT/HTML/?uri=CELEX:12002E/TXT\&from=EN (March 20, 2015). . 2015. Official Journal of the European Communities Judgment of the Court of 5 February 1963. - NV Algemene Transport- En Expeditie Onderneming van Gend \& Loos v Netherlands Inland Revenue Administration. - Reference for a Preliminary Ruling: Tariefcommissie - Pays-Bas. - Case 26-62. http://eurlex.europa.eu/legalcontent/EN/TXT/HTML/?isOldUri=true\&uri=CELEX:61962CJ0026.

European Parliament \& Council of the European Union. 2009. "Directive 2009/28/EC of the European Parliament and of the Council of 23 April 2009 on the Promotion of the Use of Energy from Renewable Sources and Amending and Subsequently Repealing Directives 2001/77/EC and 2003/30/EC." Official Journal of the European Union L140(June): 16-62.

European Union. 2016. “Regulations, Directives and Other Acts.” 2016: 20-22. https://europa.eu/european-union/law/legal-acts_en (March 17, 2015).

G. Hurowitz. 2015. The Green Tigers. 
https://d3n8a8pro7vhmx.cloudfront.net/forestheroes/pages/131/attachments/orig inal/1423259883/Green_Tigers_Report_-_January.

GATT. 1986. "The General Agreement on Tariffs and Trade." International Organization: 105. https://www.wto.org/English/docs_e/legal_e/gatt47 (March 19, 2015).

ISPO. 2015. Lampiran I Pedoman Perkebunan Kelapa Sawit Berkelanjutan Indonesia. http://www.ispo-org.or.id/images/lamp_sk19.

Jordan, A. 2005. Environmental Policy in the European Union: Actors, Institutions, and Processes (2nd Edn.). London: Earthscan.

Lembaga Riset Perkebunan Indonesia. 2009. "Menimbang Relevansi Sertifikasi RSPO." Jurnal Warta Penelitian dan Pengembangan Pertanian 31(6): 10.

M.A. Suleiman. 2014. "Transnational Private Regulations for Sustainable Palm Oil in Indonesia." SECO-WTI Project 140705(July_2014_01): 10.

http://www.wti.org/fileadmin/user_upload/wti.org/7_SECO-

WTI_Project/Publications/Suleiman_PalmRegulation_CH_Rev_May_2014-

Last_comments_CH_140705_Final_MAS_July_2014_01.

Reuters. 2013. "Argentina Files Complaint to WTO over EU Biodiesel Import Duties."

Reuters. http://www.reuters.com/article/2013/12/19/argentina-wto-biodieselidUSL2NOJYOV920131219 (March 19, 2015).

Schaus, Malorie, and Andreas Lendle. 2010. "Trade Law Clinic 2010: The EU 's Renewable Energy Directive - Consistent with WTO Rules ?" : 1-60.

http://graduateinstitute.ch/consistent_with_WTO_rule?/index_htm\%3E (March 20, 2015).

Smith, Mary Ellen, Bob Flach, Karin Bendz, and Sabine Lieberz. 2014. "EU-28 Biofuels Annual EU Biofuels Annual 2014." : 40. http://gain.fas.usda.gov/Recent GAIN Publications/Biofuels Annual_The Hague_EU-28_7-3-2014.pdf (March 21, 2015).

The Jakarta post. 2010. "EU Pledges to Continue Buying CPO from Indonesia." thejakartapost.com. http://www.thejakartapost.com/news/2010/05/17/eupledges-continue-buying-cpo-indonesia.html (March 21, 2015). 